\title{
Tanker fra rullestolen
}

\author{
For 15 år siden ble jeg utsatt for en sykkelulykke. Det resulterte i en total ryggmargsskade \\ i nivå C6-C7 med komplette lammelser derfra og ned og en forandring i livet som utløste \\ atskillige refleksjoner.
}

Heldigvis kunne jeg konstatere at den kunnskapsbase som var lagret gjennom livet, kunne hentes frem uten vanskeligheter. Jeg mener at jeg fortsatt kunne tenke nokså klart - hodet var i orden. Engasjerende arbeid i helsevesenet helt fra 1950 hadde gitt meg solid bakgrunn for å forstå min egen situasjon, selv om jeg da praktisk talt ikke hadde noen erfaringer som pasient. Disse opplevelsene avfødte et behov for skriftlig fordypning i problemene, og dette resulterte i en bok (1). Jeg håpet med dette at jeg kunne modnes til å mestre de vanskeligheter som jeg utvilsomt hadde havnet oppi. Dernest kunne boken representere en kunnskapsbase for dem som hadde vært like uheldige som meg. Med min lange erfaring fra ulike deler i helsevesenet hadde jeg et håp om å kunne gi et lite bidrag til den evigvarende debatten om utformingen av dette.

\section{Akuttfasen}

Å våkne opp på nevrokirurgisk akuttavdeling etter en ukes total amnesi er en spesiell opplevelse. Fra en soporøs tilstand fikk jeg etter hvert økende erkjennelse av realitetene. Med halskrage og larynxtube gjennom halsen og uten språk måtte jeg prøve å orientere meg om tingenes tilstand. Det første jeg registrerte var at familien var der - min kone Liv, mine barn og mine søsken - støtteapparatet var til stede.

Kommunikasjon ble ordnet via et opptegnet alfabet og pekemetoden. Den varme kontakten som straks ble etablert, bygde opp optimismen og troen på fremtiden. Men med død kropp, elendig fingerfunksjon og nedsatt armbevegelighet var situasjonen lite oppmuntrende. Imidlertid var denne restfunksjonen meget viktig - den skulle gi meg et brukbart liv tilbake. Den måtte stimuleres og pleies, og jeg mener at jeg fikk en god start ved nevrokirurgisk akuttavdeling på Ullevål. Ressursene måtte jeg hente frem selv, og den prosessen startet tidlig etter oppvåkningen.

Det begynte med erkjennelsen: Jeg kunne ikke gå, sykle eller bruke ski. Som ihuga friluftsmann ville dette bli et stort savn. Min trøst ble at jeg hadde mange gode minner fra levd liv lagret i hele mitt genap- parat, og de kan hentes frem ved behov og fortsatt gi meg lykkelige stunder. Livsløpet hadde vel også bygd opp en kraft til å møte ubehagelige hendelser. Mine krigserfaringer som tenåring har paradoksalt nok gitt meg en fysisk og mental basis som det må være vanskelig å oppnå i vårt moderne velferdssamfunn. Jeg har også utvilsomt arvet gener fra tidligere generasjoner, som jeg har kjennskap til tilbake til mine tippoldeforeldre. Håpløse sosiale forhold for de underprivilegerte tvang dem til å forlate hjembygda. Likevel greide de med strev og slit å løfte sine åtte barn opp til en god levestandard.

Møtet med en godt administrert akuttavdeling var en positiv opplevelse. God personellkontakt med adekvat informasjon og trygghetsfølelse døgnet rundt bygde opp optimismen jeg så sårt trengte. Opptreningen var begynt. Jeg så frem til fortsettelsen på Sunnaas sykehus.

\section{Rehabilitering}

Nesoddlandet midtsommers er et fint sted å være. Eneværelse med fjordutsikt ga optimale mentale betingelser for Liv og meg. En stab av fagfolk tilrettela rehabiliteringen, og den begynte straks. Liv kunne bo på stedet $\mathrm{i}$ perioder, hun var den beste støtte jeg kunne få.

Treningen med fysioterapeut foregikk i sengen. Reiste jeg meg opp, svimte jeg av. Tilpassede korsetter ble snørt på meg for å bedre blodsirkulasjonen, og med økende trening ble det gradvis lettere å sitte oppe. Ergoterapeuten trente fingerferdigheten.

Med spastiske fingre som strittet $\mathrm{i}$ alle retninger, var det ikke lett, men fremskrittene meldte seg snart. Etter hvert kunne jeg sitte i rullestol og ble trillet til en treningshall og kunne trene sammen med andre. Lammelsene holdt seg uforandret, men bedrede funksjoner ga meg mot til å tro på et godt liv.

\section{Komplikasjoner}

Med sterkt reduserte fysiske ressurser måtte jeg forvente at komplikasjonene ville melde seg. Kroppsfølelsen var totalt forandret, og det var ikke lett å tolke symptomer som måtte melde seg. Inkontinensen var ubeha- gelig nok, men pleiepersonalet mestret den bra. Jeg ble lett trett og var plaget av kvalme. Regimet omfattet behandling med sovemedisin og beroligende tabletter, noe jeg ikke var vant til. Jeg ønsket og fikk tablettene seponert, og kvalmen og søvnigheten forsvant. Automatisk medisinering uten individuell vurdering er et tankekors (2).

For lamme pasienter er sår på de lammede partiene det største skremselet og bøygen. Det skulle forsure livet mitt i år fremover. Et sår dukket opp midt på høyre setehalvdel, uten at det ble klart for meg hvordan det oppsto. Trykksår er et kjent problem, og i sykehus bør rutinene være så gode at slike ikke forekommer. Uheldige hendelser $i$ helsetjenesten er vanlig og skyldes oftest systemfeil (3).

Såret fikk store konsekvenser. Bassengtrening, en viktig del av opplegget, måtte seponeres. Mye dyrt bandasjemateriell ble forbrukt på såret. Til ingen nytte - det grodde ikke. Jeg hadde ingen lokale symptomer, det virket beskjedent, men jeg følte meg ikke i form og det gikk utover treningen. Avlasting med mageleie og leieforandring dag og natt var plagsomt. Tilsyn av plastisk kirurg ga løfte om at såret snart ville gro. Men det grodde ikke. Utover høsten fikk jeg urinveisinfeksjoner og lungeempyem, som ble behandlet ved Ullevål. Et belastet immunapparat kan forklare infeksjonsspredningen. Før jul var jeg kommet såpass til hektene at jeg ønsket å være hjemme julaften. Jeg hadde ikke vært der siden jeg ble skadet, og tre dager i eget hjem var balsam for sjelen.

Vel tilbake på Sunnaas steg feberen, uten at årsaken var klar. Jeg var i dårlig forfatning, radmager og med meget lav blodprosent. Retur til Ullevål avslørte et underminert sår infisert helt inn til beinet. Heldigvis var Ole der, gammel kullkamerat og pensjonert professor i plastisk kirurgi som fortsatt var i aktivitet. I begynnelsen av nyåret foretok han en stor lappeplastikk. Såret grodde, og senere har det ikke vært tegn til sårdanning på operasjonsstedet. Jeg kom meg raskt og returnerte til Sunnaas i fin form. Men en liten restglipe i såret avslørte meticillinresistente gule stafylokokker og 
nødvendiggjorde retur til Ullevål nok en gang. Forbud mot antibiotika av redsel for ny resistens førte til at jeg måtte drive ondskapen ut «med egne midler» $\mathrm{i}$ isolat. Det ble lange dager. Utpå våren slapp jeg opp $i$ en manuell rullestol og kunne trille $i$ lange sykehuskorridorer og ut $\mathrm{i}$ vårsolen.

Sammen med Liv hadde jeg fine turer over hele sykehusområdet, og det var hun og våren som bidro mest til at jeg kunne returnere til Sunnaas ut i mai, frisk og velfødd.

Gode puter og madrasser har bidratt til at det senere ikke er registrert trykkmerker på setet. En tendens til tynn hud over sitteknokene førte til at disse etter hvert ble meislet bort. Dette forløp ukomplisert på høyre side, men på venstre er jeg blitt reoperert tre ganger på grunn av abscessdanning $i$ arret. Verken jeg eller pleiepersonalet registrerte forandringer før pusset tømtes spontant. Hematogen infeksjon var sannsynlig. Plastikkirurgene ved Rikshospitalet ga ikke opp, og i august 2007 ble det foretatt en nitid og omfattende operasjon. Såret grodde uten komplikasjoner og har vært bra siden. Jeg hadde da passert 80 år. Alder bør ikke være noe hinder for behandling (2).

Helsepersonell bør ha spesialinstruks for behandling av lammede for å unngå sårkomplikasjoner. Min erfaring er at det mangler mye på det. Kontroll og operasjoner må overvåkes av spesialister. Det er lett å regne ut at mine sår har kostet helsevesenet svære beløp. De burde vært spart.

\section{$\emptyset$ konomi}

En tetraplegiker er dyr for samfunnet. Også for pasienten selv koster det å være lam. Vi hadde en bolig på Ringerike som var nærmest utilgjengelig for meg. Ombygging ville blitt dyrt og ta lang tid. Tilgjengelige boliger var nærmest ikke-eksisterende i 1995. Liv brukte lang tid på å finkjemme markedet. Vi fant én i et sameie på Stabekk. Det ville koste oss en million kroner å bytte ut vår enebolig på Ringerike, med utsikt over by og blåner, med en leilighet ved Stabekk stasjon. Vi var i en tvangssituasjon og måtte telle penger. Under denne prosessen ble pensjonen sterkt redusert. Resistente gule stafylokokker påført på Ullevål hadde ført til forlenget sykehusopphold, som jeg måtte betale en egenandel for.

Jeg hadde temperament nok til å reagere på urettferdigheten, og med hjelp fra Sunnaas sykehus søkte vi Norsk pasientskadeerstatning for å få dekket merutgiftene. Etter et par år fikk jeg svar: Avslag. En rekke eksperter jeg ikke kjente hadde uttalt seg. Saksbehandlingen kostet trolig mye mer enn et eventuelt skadebeløp.

Sunnaas sykehus er en informasjonsbase for hjelp og støtte. Vi fikk meget god innføring i økonomiske spørsmål av en rullstolbrukende skattejurist. Støtteordninger og skatteregler ble belyst i muntlig og skriftlig form (4). Reglene for «særfradrag ved store sykdomsutgifter» ble detaljert klargjort.
Med min nesten totale uførhet måtte jeg regne med ekstrautgifter. Jeg ble tvunget til å flytte fra mitt kjære hus til en tilpasset bolig i Bærum. På selvangivelsen trakk jeg fra flytteutgiftene. Blankt avslag fra en likningssekretær. Klage til likningsnemnda førte til innrømmelse av 5000 kroner, som skulle dekke tømming og klargjøring av en enebolig og flytting og innredning av en ny bolig. Legeattesten vedlagt selvangivelsen forklarte i klartekst min situasjon, men systemet overprøvde denne.

Den årlige selvangivelsen ble senere også problematisk. Ny legeattest ble krevd hver gang, selv om tilstanden var erklært som varig og uforanderlig. Særfradraget for store sykdomsutgifter ble ført opp etter beste evne, men forskjellige likingsfunksjonærer behandlet det ulikt - alt fra noen innrømmelser til avslag. Jeg prøvde å få til en fast ordning, siden utgiftene var omtrent de samme fra år til år. Det ville spart meg og vesenet for mange problemer, men en slik ordning er det vanskelig å få til. Skriftlig dokumentasjon av alle utgifter selv om de er meget sannsynlige er en slitsom øvelse for gamle mennesker.

\section{Utvikling}

Om myndighetspersoner laget vanskeligheter, er vår velferdsstat $i$ prinsippet innstilt på at problemer skal mestres. I vår nye, tilpassede leilighet ble forholdene lagt til rette for det. Den lokale ergoterapeuten har vært en god støttespiller som har skaffet nødvendig utstyr gjennom hjelpemiddelsentralen. Den har utviklet seg til å bli en meget effektiv institusjon for reparasjoner og nyanskaffelser. De praktiske løsninger av dagliglivets problemer har kona og jeg stort sett måttet pønske ut selv. Prøving og feiling har gradvis gitt oss et bedre liv.

Forflytning og hygiene er hovedproblemene. En ideell personløfter til stående stilling har løst problemet. Jeg løftes med et tastetrykk og dusjes stående, og én pleier greier morgen- og aftenstellet uten tunge løft. Kroppsvasken skjer ved toalettet, løftingen opp og ned aktiviserer peristaltikken, og jeg holder meg stort sett tørr resten av døgnet. Dette krever rutiner som blir vanskelige for mange nye, uøvde pleiere, men de rutinerte har et lett arbeid og er også fornøyd med at de gjør en god jobb.

Det ble skaffet tilpasset bil et par år etter skaden. Min elektriske rullestol kobles til førerplassen. Med tastetrykk åpnes dører og heis når jeg skal fra leiligheten ned $i$ garasjen, og med nye tastetrykk åpnes bildøren, en rampe felles ned og jeg kan kjøre inn og feste stolen bak rattet.

Jeg var fortrolig med tekstbehandling på PC før skaden. Etter hvert kom e-post og Internett i tillegg, og verdensveven har gitt meg et kunnskapstilfang som i høy grad har beriket hverdagen. PC-en ble en erstatning for min ødelagte fingerferdighet, og data om mine erfaringer kunne gis skriftlig form.
På denne måten har jeg fått et tilnærmet normalt liv langt utover det vårt helsevesen har kunnet makte.

«Den elektroniske verden» har fătt økende betydning for vårt hverdagsliv. Kunnskap om fysikk har ikke bare gitt oss datateknologien, men også redskaper til å trenge inn i biologien - i naturens mysterier. Dette ga oss i 1953 detaljstrukturen i det viktigste molekylet i naturen: DNA, molekylet som kan motta, lagre og overføre informasjon og som inneholder resepten for produksjon av alle viktige stoffer i den levende natur (5). Det har gitt oss forklaringen på hvordan naturen styres gjennom fysiologiske prosesser, som er mestringsmønsteret for alt levende liv på kloden (6). DNA finnes i alle levende celler, det forteller noe om samhørigheten i naturen, som Arne Næss filosofisk har utdypet i sin økosofi (7). Medisinen befinner seg i begynnelsen av en utvikling med DNA-forskning som kan gi enorme muligheter for bedret diagnostikk og behandling, både på det individuelle og det globale plan. Disse perspektivene gir grunnlag for mange refleksjoner (1).

Jeg synes det er grunn til optimisme, og nå, i mitt 84. år, er jeg rimelig fornøyd med livet. Jeg har hatt utbytte av å gi mine erfaringer skriftlig form, og jeg har behov for å dele disse erfaringene med andre. Bokmarkedet er slik at jeg har måttet mestre utgivelsen selv, men arbeidet har vært fruktbart. Jeg tror jeg har oppnådd en optimal tilværelse ut fra de betingelser livet har gitt meg.

\section{Ola Rygh}

olryg@online.no

Jernbaneveien 45

1369 Stabekk

Oppgitte interessekonflikter: Ingen

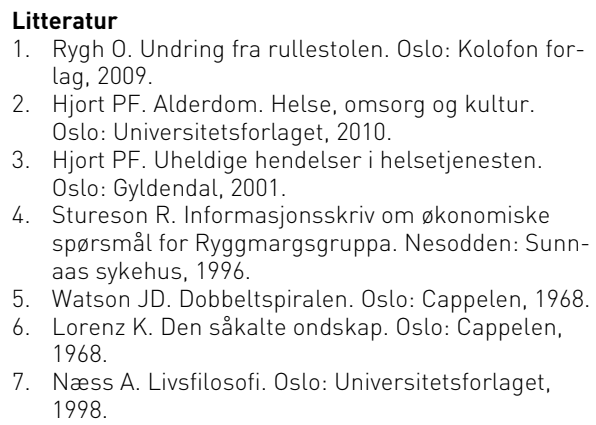

Manuskriptet ble mottatt 20.5. 2010 og godkjent 17.6. 2010. Medisinsk redaktør Erlend Hem. 